„Bohemistyka” 2021, nr 4, ISSN 1642-9893

Jiří NOVOTNÝ

DOI: 10.14746/bo.2021.4.6

Západočeská univerzita v Plzni

\section{Kosmova kreativní nápověda?}

Keywords: Czech literature, hagiography, historiography, early middle ages, Ludmila, Kosmas, Mělník, Pšov

Klíčová slova: Česká literatura, hagiografie, historiografie, raný středověk, Ludmila, Kosmas, Mělník, Pšov

\section{Abstract}

The first book of Kosma's Chronicle of Bohemia shows a significant anomaly Kosmas violated the continuous chronological composition of the first book and, describing the beginnings of the Christianization of Bohemia in the second half of the 9th century, inserted an extensive episode between the dates of Prince Borrivoj I and his century, inserted an extensive episode between the dates of Prince Bořivoj I and his
wife Ludmila about the death of the lucky prince Vlastislav. It is possible that the oldest Czech chronicler indirectly - but consciously - drew attention to the true origin of Princess and later saint Ludmila, about whom there are still disputes.

První kniha Kosmovy Kroniky Čechů vykazuje výraznou anomálii. Kosmas porušil kontinuální chronologickou kompozici první knihy a při líčení počátků christianizace Čech ve 2. polovině 9. století vložil mezi data knížete Bořivoje I. a jeho ženy Ludmily rozsáhlou epizodu o smrti luckého knížete Vlastislava. Je možné, že nejstarší český kronikář nepřímo - ale vědomě - upozornil na pravý původ kněžny a pozdější světice Ludmily, o kterém se dodnes vedou spory.

\section{Prolog}

Autor nejstarší české kroniky převyprávěl příběhy Čechů od předhistorických mýtů (nejstarší české pověsti) po historické události počátku 12. století. Poměrně pregnantně dodržoval obvyklé kompoziční schéma; $\mathrm{v}$ chronologickém sledu událostí jednotlivých knih Kroniky Čechů zaznamenal předhistorické a historické děje obyvatel českého knížectví. Postupoval promyšleně od nejstarších dob k prv- ním dekádám 12. věku (do roku 1125), které odpovídaly závěrečnému období jeho života osobního, profesního i autorského - „literárního”. Chronologická kompozice kroniky však vykazuje hned v první knize zajímavou, výraznou a nestandardní anomálii. $\mathrm{V}$ celém díle sice najdeme několik drobných kompozičních odchylek, ale ty nepůsobí dojmem autorského záměru.

Jinak je tomu právě v úvodní knize Kosmova díla, kde narážíme na zvláštní - avšak dodnes prakticky opomíjenou - „kompoziční aluzi”. ${ }^{1}$ Kronikář vstoupil do českých dějin vyprávěním o př́íchodu kmene vedeného praotcem, pokračoval drobnou epizodou soudce Kroka, aby po charakteristice jeho dcer plynule přešel k přemyslovské dynastické pověsti. Po ní je do první knihy zakomponována dívčí válka, která měla být obdobím konce ženské rovnoprávnosti či dominance - v samém závěru př́běhu čteme, že se během pohanských slavností muži zmocnili př́tomných žen a podmanili si je. Kosmas následně vyjmenoval známou řadu pohanských knížat vládnoucích po Přemyslu Oráči, která končí Hostivítem a jeho potomkem Bořivojem, prvním historickým knížetem, křest’anem a podle Kristiánovy legendy budovatelem nejstarších kostelů v zemi i nové metropole Prahy (Ludvíkovský 1978, s. 18-27).

Logicky bychom dále očekávali kronikářův přirozený chronologický postup a představení prvních historických generací vládnoucích Přemyslovců, které budovaly kontury raně středověkého českého státu na přelomu 9. a 10. století - Spytihněv I., Vratislav I. (Bořivojovi synové) a Václav (Bořivojův vnuk). Kosmas ale zvolil neobvyklý kompoziční př́stup a vydal se jiným směrem. Po lakonické zmínce o Bořivojově moravském křtu oznámil nestandardní retrospektivu:

Nec superfluum esse iudicavimus, quod referente fama audivimus, huic operi nostro hoc in loco summatim literarum apicibus inserere bellum, quodque olim antea

\footnotetext{
${ }^{1}$ Záměrně používáme pojem „kompoziční aluze”, protože uvažujeme o zřetelném a promyšleném autorském záměru, jehož cílem mohlo být upozornění na důležitou historickou souvislost - vazbu rodinného původu první české historické kněžny a světice Ludmily na oblast středního Poohří, patrně ovládanou ještě v 9 . století tř. Lučany.
} 
retro dierum tempore ducis Neclan in campo, qui dicitur Turzko, consertum est inter Boemos et Luczanos, qui nunc a modernis ab urbe Satc vocitantur Satcenses (Bretholz 1923, s. 22-232).

[Nepokládali jsme však za zbytečné do tohoto našeho díla na tomto místě vložiti stručné vylíčení toho, čeho jsme se z pověsti doslechli o bitvě svedené dávno před tím za času knížete Neklana na poli zvané Tursko, mezi Čechy a Lučany, jimž v dnešní době podle hradu Žatce říkáme Žatčané.]

Po této „vysvětlivce” následuje rozsáhlá pasáž textu, která se vrací do doby vlády pohanského knížete Neklana ${ }^{3}$ a líčí průběh tzv. lucké války. Na této skutečnosti by nebylo nic výjimečného, kdyby se autor znovu nevrátil po ukončení líčení lucké války $\mathrm{k}$ Bořivojovu křtu v souvislosti s koncem vlády moravského krále Svatopluka - a v další kapitole neuvedl analistický zápis ${ }^{4}$ týkající se původu Bořivojovy ženy Ludmily:

Borivoy autem genuit duos filios Spitigneum et Wratizlaum, ex ea, quae fuit filia Zlaviboris, comitis de castello Psov, nomine Ludmila (Bretholz 1923, s. $34^{5}$ ).

Kronikář se tedy věnoval po rozsáhlém líčení průběhu lucké války, kterou s jistou mírou rozpaků můžeme považovat za meziregionální konflikt vládců stř̌edních Čech a části Poohří někdy v polovině 9. sto-

${ }^{2}$ Při popisu tzv. Lúky - úrodné oblasti ovládané Lučany - Kosmas následně vysvětluje, jak se $v$ raném středověku přenášelo označení regionu na obyvatele v něm usedlé (srov. Kosmas 1975, s. 26). Překlady latinských textů: Karel Hrdina (Kosmas); Jaroslav Ludvíkovský (Kristián, Diffundente); Bohumil Ryba (Fuit), Václav Vladivoj Tomek (AGO). Překlad staroslověnského textu: Emilie Bláhová a Václav Konzal (Prolog).

${ }^{3}$ Mělo by se tedy jednat nejpozději o polovinu 9 . století. Kosmas uvedl, že po Neklanově odstoupení vládl Hostivít, Bořivojův otec. Bořivoj I. se narodil podle určitých hypotéz v padesátých letech 9. věku (srov. Třeštík 1997, s. 195).

${ }^{4} \mathrm{~S}$ největší pravděpodobností se jedná o lakonické zaznamenání Ludmilina původu čerpané ze starých domácích análů, s uvedením jména a sociálního statusu Ludmilina otce i toponyma hrádku (castellum), na kterém měl její otec - předák (comes) Slavibor - sídlit.

5 „Bořivoj zplodil dva syny, Spytihněva a Vratislava, z té, která byla dcerou Slavibora, předáka z hrádku Pšova, jménem Ludmily” (Kosmas 1975, s. 34) letí, opět Bořivojovi a jeho ženě Ludmile. Proč? Z jakého důvodu rozdělil právě luckou válkou jinak logicky navazující zprávy o nástupu Bořivoje I., jeho křtu, sňatku a narození potomků - nástupců na knížecím stolci?

Domníváme se, že byla jednou z příčin včlenění rozsáhlé retrospektivní epizody, Písni o Vlastislavově tragickém konci (Karbusický 1995, s. 101-157), ${ }^{6}$ mezi Bořivojova data právě informace o původu kněžny Ludmily, kterou Kosmas nemohl, nebo nechtěl uvést s náležitým vysvětlením. Bud' se ještě v jeho době nemohlo - např́iklad z politických důvodů souvisejících s dávnou genocidou ${ }^{7}$ nobility v Poohří hovořit a psát, nebo si nebyl lokací starobylého Pšova zcela jist a jen naznačoval... Př́ičin může být celá řada.

Opakování informace o Bořivojově konverzi má sice logiku, protože od druhého uvedení motivu s datem křtu (byt' chybného) Kosmas nadále poctivě sledoval chronologickou linku známou mu především z domácích análů i ze zahraničních pramenů, kterou dále literárně i faktograficky obohacoval. Nevysvětluje to ale skutečnost, proč zakomponoval právě luckou válku bezprostředně za poprvé uváděný motiv Bořivojova křtu, když se podle něj měly válečné události odehrát „dávno před tím” - tedy dávno před Bořivojovým odjezdem na Moravu (Kosmas 1975, s. 26).

\section{Domovy}

Jde nám tedy o Ludmilin původ; $\mathrm{v}$ rámci hypotézy, zda nám nenaznačil poměrně dobře informovaný Kosmas něco navíc, něco,

\footnotetext{
${ }^{6}$ Karbusického postřehy jsou nesmírně zajímavé, přestože se s některými jeho názory neztotožňujeme (především s datací luckého konfliktu do 10. století a s názorem, že si Kosmas se zařazením lucké epizody kompozičně nevěděl rady), je třeba jim věnovat pozornost.

${ }^{7}$ Kosmas uvedl nejen smrt luckého knížete Vlastislava, plenění jeho země, boření hradů, ale i vraždu Vlastislavova malého synka. Zmínil také koncentraci rozprchlého luckého obyvatelstva do nížinného „nového hradu” Drahúš u Postoloprt (existující lokalita), který byl patrně vítězi dobře kontrolovatelný.
} 
o čem sice můžeme živě diskutovat, ale co je možné za vydatné pomoci archeologie a toponomastiky částečně rekonstruovat.

V př́ípadě Ludmily se jedná o první historicky doloženou českou kněžnu, manželku knížete Bořivoje I., později korunovanou atributem svatosti, jejíž původ je dodnes zahalen rouškou tajemství. Mezi českou laickou i odbornou veřejností převládá přesvědčení, že pocházela ze středočeského Mělníka, hradiště a pozdějšího městského centra vypínajícího se v dominantní poloze nad soutokem Labe s Vltavou. Mělnický původ české kněžny a světice je silně zakořeněn v české tradici, přestože neexistují nezvratné důkazy pro takové tvrzení. $\mathrm{K}$ tomu všemu se v minulém století mezi českými badateli poměrně intenzivně diskutoval (a diskutuje dodnes) možný Ludmilin zahraniční původ, nejčastěji uváděný do souvislosti s oblastí obývanou Lužickými Srby (srov. Profantová 2020, s. 57; Tomášek 2020, s. 75-87).

Zahraniční původ kněžny je pro mnohé jistě lákavý, nebot tím začleňuje politickou realitu středních Čech 2. poloviny 9. století do určitého nadregionálního ${ }^{8}$ kontextu, ale je třeba zdůraznit, že pro zahraniční variantu neexistují prakticky žádné relevantní důkazy. Celá konstrukce je založena na ojedinělé pozdní informaci hagiografického pramene ${ }^{9}$ a opatřena dalšími málo věrohodnými argumenty. ${ }^{10}$

Zkoumáme-li totiž veškeré dostupné literární prameny, docházíme $\mathrm{k}$ přesvědčení, že je zahraniční původ takřka vyloučen a oproti tomu ten domácí postaven na sice rozsáhlejších, avšak poměrně vratkých

${ }^{8}$ Vyhýbáme se výrazu „mezinárodního”, jelikož novodobou skutečnost nemůžeme bez širších komentářu aplikovat na situaci střední Evropy 2. poloviny 9. století.

${ }^{9}$ Jedná se o tzv. slovanský Prolog z 12.-13. století, jehož staroslověnské i latinské předlohy (včetně uvažovaného staroslověnského archetypu) jsou předmětem hypotéz na bázi konstrukti̊ novověké textové kritiky.

${ }^{10}$ Především zmíníme názor historika V. Chaloupeckého o stáŕí legendy Diffundente sole; určitá nedopatření zjišt'ujeme také v prŕslušné edici primárního textu upřednostnění méně četné rukopisné varianty Mělnicka i zanesení zcela zásadního obratu de gente sua (vyjadřující vztah mezi původem Ludmiliným a Bořivojovým) pouze do komentáře, přestože je obrat součástí textu drtivé části dochovaných rukopisů (srov. Chaloupecký 1939, s. 154, 489; 1942, s. 99, 270). základech. Pro získání základního přehledu níže uvedeme ${ }^{11}$ dostupné pramenné podklady, abychom si uvědomili, o co se opírají dosavadní argumenty a na čem budou konstruovány nové pohledy, které si dovolujeme prostřednictvím studie předložit $\mathrm{k}$ širší odborné diskusi:

- Legenda Fuit - 10. století (Chaloupecký 1939, s. 467; 1942, s. 60): Fuit in provincia Boemorum quidam comes, nomine Boriwoy, paganico adhuc vivens more, et accepit uxorem de alia provincia, $f i$ liam Zlawyboris comitis, nomine Ludmillam... [Byl v zemi české jeden kníže, jménem Bořivoj, žijící i tehdy ještě v obyčejích pohanských, a vzal si za manželku z jiné země dceru knížete Slavibora, jménem Ludmilu.];

- Kristiánova legenda - 10. století (Ludvíkovský 1978, s. 24, 25): Habuit eciam et uxorem nomine Liudmilam, filiam Slaviboris comitis ex provincia Sclavorum, que Psou antiquitus nuncupabatur, nunc a modernis ex civitate noviter constructa Mielnik vocitatur. [Měl také manželku jménem Ludmilu, dceru knížete Slavibora, z kraje slovanského, který se dřive jmenoval Pšov a který dnešní lidé nazývají nyní podle nově vystavěného hradu Mělnickem.];

- Kosmova Kronika Čechů - 1125 (Bretholz 1923, s. 34; Kosmas 1975, s. 34): Borivoy autem genuit duos filios Zpitigneum et Wratizlaum ex ea, que fuit filia Zlaviboris, comitis de castello Psov, nomine Ludmila. [Bořivoj zplodil dva syny, Spytihněva a Vratislava, $\mathrm{z}$ té, která byla dcerou Slavibora, předáka z hrádku Pšova, jménem Ludmily.];

- Anály hradišt'sko-opatovické (dále jen AGO) - před 1150 (Emler 1874, s. 387): Borivoi vero dux iam tocies nominatus duos genuit $f i$ lios, Zpitigneum et Vratizlaum, de Ludmila, Zlavoboris comitis filia, de castello Psov nomine orta. [Bořivoj kníže však již tolikrát jmenovaný zplodil dva syny, Spytihněva a Vratislava, s Ludmilou, dcerou hraběte Slavibora, narozenou na hradě jménem Pšov.];

${ }^{11}$ Jednotlivé textové sekvence jsou opatřeny českým ekvivalentem a doplněny uvedením hagiografického či historiografického zdroje s přibližným datem jeho vzniku. Datace je třeba považovat $v$ řadě př́ípadů za hypotetické, přestože vycházíme z akceptovatelných konstruktů historické i literární vědy. 
- Prolog o sv. Ludmile - 12./13. století - překlad ze staroslověnštiny (Bláhová 1976, s. 273): Blahoslavená Ludmila byla ze zemé srbské, knižete srbského dcera;

- Legenda Diffundente - 13. století (Chaloupecký 1939, s. 489; 1942 s. 99): Hic dum excellentissime forme et egregie iuventutis flore nitesceret, accepit uxorem, nomine Ludmillam, filiam scilicet comitis nomine Slawibory, de provincia Melnicensi, que cum esset iuvencula, ydolis ymolabat. [Ten skvěje se květem vynikající krásy a mladistvé síly, pojal manželku jménem Ludmilu, dceru knížete jménem Slavibora, ze země mělnické, ${ }^{12}$ jež jako mladá dívka obětovala modlám.];

- Dalimil - 14. století (Daňhelka 1988, s. 328, 333-334):

\author{
Ta jest byla žena Bořivojova \\ a hrabinka ze Pšova. \\ Jemuž tehdy Pšov diechu, \\ témuž pak Mělník vzděchu. \\ Neb př̌̌d Mělníkem hrad bieše, \\ ten sobě jmě Pšov jmějieše. \\ A pod městem potóček teče, \\ Ten sobě Pšovka řeče.
}

Prostudujeme-li pozorně nejstarší písemné zmínky o Ludmilině původu, je zřejmé, že oscilují mezi zemí (provincia) a hrádkem (castellum) - přičemž Kristián kontaminuje zemi s názvem hrádku. Kristiánovu vysvětlivku spojující dávný Pšov s Mělníkem však musíme považovat za pozdní doplněk; prakticky shodná textová interpolace se totiž objevuje v jednom z pozdních rukopisů Kosmovy Kroniky Če-

vzniku. Datace je třeba považovat v řadě případů za hypotetické, přestože vycházíme $\mathrm{z}$ akceptovatelných konstruktů historické i literární vědy.

${ }^{12}$ Opravujeme ediční variantu na provincia Melnicensi (země mělnická). Předmětná pasáž by měla vypadat (podle převažujících variant dochovaných rukopisů) as následovně: ,[...] accepit uxorem, nomine Ludmillam de gente sua, filiam scilicet comitis nomine Slawibory, de provincia Melnicensi [...]". Podle Diffundente se tedy jednalo o Ludmilu z téhož lidu (rodu - dnes národa?) jako Bořivoj, pocházející ze země mělnické. chư, ${ }^{13}$ takže lze vyslovit hypotézu o nepůvodní interpolaci, o informaci, která v Kristiánově či Kosmově autografu původně nefigurovala a k textu byla připsána až někdy po polovině 12 . století, kdy už byl Mělník obecně známým sídlem tamější kapituly. ${ }^{14}$

Opakovaně jsme se také v minulosti vyjadřovali k tomu, že je pravděpodobně třeba variantu Kosmovu i $A G O$ považovat za původní, nebot' obsahem i formou poměrně přesně odpovídá obvyklým analistickým šablonám (Novotný 2013, s. 2988). O předpokladu, že byli autoři obou textů inspirováni starými domácími anály, ostatně netřeba pochybovat; historická věda s tímto názorem běžně pracuje (Tř̌štík 1966, s. 54).

Nejmladší z pramenů, Kronika tř. Dalimila, si ale také zaslouží výraznější komentář, protože přichází s označením hydronyma Pšovka, a to se nikde jinde neobjevuje. Kronika je kompilačním pramenem vrcholného středověku, čímž je její výpovědní hodnota významně limitována. Ale přesto je třeba se zamyslet nad tím, odkud a co její autor čerpal. Na první pohled registrujeme Dalimilovu závislost na Kristiánovi či Diffindente, což nás nepřekvapí, ale níže bude třeba vysvětlit uvedení hydronyma Pšovka, protože je pravděpodobné, že bylo

\footnotetext{
${ }^{13} \mathrm{~V}$ př́íslušné edici Kosmova textu čteme na konci odkazu e), jímž je variantně komentován výraz Pšov (Psow, Pson): „qui nunc Mielnik dicitur ergänzt im Rande C1 ${ }^{\text {b” }}$ (Bretholz 1923, s. 34). Uvedený Fürstenberský rukopis je pak níže (III. Die Handschriften, s. LXXVIII) datován do 15. století. Ve starší edici Kosmovy kroniky sledujeme totéž na konci poznámky č. 2: „,2aa dokládá po straně, qui nunc Mielnik dicitur" (Emler 1874, s. 28). S ohledem na stáŕí rukopisu se lze domnívat, že mohl být př́ípis motivován dokonce až tř. Dalimilem.

${ }^{14}$ Dobu realizace pozdního doplňku odvozujeme od skutečnosti, že je legenda Diffundente sole, v níž se zmínka o Mělníku také objevuje, považována za odvozeninu z Kristiánovy legendy sepsanou pravděpodobně až ve 13. století. Pakliže zachytili ještě Kosmas i $A G O$ před polovinou 12. století informaci o Pšovu bez dalšího vysvětlení a místního určení, musel se př́ípis do původní textové podoby dostat počínaje 2. polovinou 12. století. Rozhodně nelze souhlasit s konstrukty, že si byl Kosmas jist Ludmiliným původem z Mělnicka nebo že z Kristiánova textu vycházel a dovětek o Mělníku klidně vypustil, nebot' znal pravé souvislosti (srov. Tomášek, Izdný 2020, s. 66-71).
} 
v Dalimilově době (na počátku 14. století) známé a kronikář tohoto povědomí pohotově využil k verifikaci informace o Mělníku = Pšovu. Současně si musíme všimnout významné disproporce, která se paradoxně vrací zpět ke staré analistické tradici - na rozdíl od Fuit, Kristiána a Diffundente v Dalimilově textu znovu figuruje hrad, nikoli země (provincia).

$\mathrm{K}$ vysvětlení drobných i zásadnějších disproporcí v primárních písemných pramenech i k uvedení Pšovky se na příslušném místě ještě vrátíme. Pozdní interpolace starších textů (Kristiánova i Kosmova) i mladší písemné prameny (slovanský Prolog, legenda Diffundente, tř̆. Dalimil) totiž vnesly minimálně od 13. století do problematiky Ludmilina původu takový chaos, že jsou jím historická a literární věda výrazně ovlivněny dodnes.

\section{Archeologie}

K zahraničnímu původu kněžny Ludmily se již vracet nebudeme; zamyslíme se raději nad možností, zda mohl Mělník v raném středověku odpovídat starobylému Pšovu (Pšovsku) - hradu, či regionu země. Pokud dnes chceme ztotožnit mělnickou exponovanou polohu s Pšovem starých českých análů (castellum Psov), je třeba mít nezpochybnitelnou jistotu, že již nejpozději v polovině 9 . století stála v prostoru dnešního Mělníka fortifikace - uvažujeme ale o méně významném hrádku (castellum), nikoli hradu (castrum, oppidum, civitas, civitas metropolis) s významnou sídlení, vojenskou či správní funkcí.

Ve shodě s některými odborníky (Turek 1975, Bláhová 1986) se domníváme, že latinská terminologie raně středověkých sídel (a nejen sídel) hraje podstatnou roli v interpretaci literárních pramenů a vnáši více světla do rané české historie. Latinské termíny sice mohou být pouhými přepisy starších předloh (loci communes), ale nemusí se jednat o pravidlo. Za typický př́klad opaku považujeme mnohokrát skloňovaného Kosmu, jehož latinská terminologie ${ }^{15}$ si zaslouží ob-

\footnotetext{
${ }^{15}$ Nejedná se pouze o kontext kronikářových vyjádření, do kterých zakomponoval termíny comes či castellum, pozornost si zaslouží kompletní terminologie
}

zvláštní pozornosti. $V$ př́ípadě Mělníka ale neřešíme, do jaké míry byl, či nebyl významným správním centrem; prozatím hledáme základní argumenty $\mathrm{k}$ prohlášení, zda mohl stát již v polovině 9 . století a fungovat jako sídlo významného předáka Slavibora, Ludmilina otce.

K takovému prohlášení ale chybějí nezpochybnitelné důkazy, byt jsou někteří odborníci patrně přesvědčeni o opaku (srov. Meduna 2003, s. 378; Profantová 2020, s. 32). Archeologové se pokoušejí a nadále budou pokoušet posunout raně stř̌edověké osídlení Mělníka hlouběji do 9. století, ale to zdaleka nestačí. Je třeba mít jistotu, že již $\mathrm{v}$ polovině 9 . věku stálo na uvažovaném místě opevněné sídlo. S názorem P. Meduny ${ }^{16}$ který se stavu na Mělnicku systematicky věnuje řadu let, bohužel prozatím souhlasit nemůžeme a očekáváme, že další př́padné výzkumy vnesou do problematiky raného opevnění Mělníka více světla.

My prozatím nabízíme jinou cestu, variantu, která neodporuje písemným pramenům a je do určité míry akceptovatelná historicky (analýza dostupných písemných pramenů, archeologie) i lingvisticky (toponomastika). Uvažujeme o lokalitě, na níž a v jejímž blízkém

vládců a dalších sociálních skupin, ale i regionů, oblastí, hradů atp. Jen letmý pohled na Kosmou uváděné hrady Libušín, Drahúš a Dřevíč opatřené př́islušným pevnostními a polohovými atributy je toho jasným důkazem. Na potvrzení správnosti předpokladů o specifičnosti (tendenčnosti) využívání latinské terminologie v nejstarších českých literárních pramenech jsme pracovali se studenty bohemistiky v Plzni řadu let.

${ }^{16}$ P. Meduna k Mělníku: „Na dohled seskupení hradišt’ pražské kotliny stálo tedy téměř uprostřed pomyslné obilnice a ve strategické poloze na vodní cestě v 9 . stolet hradiště..." (Meduna 2003, s. 378). Pouhá teze o 9. století není postačující Historikové obecně jsou jednak silně motivováni zněním Kristiánovy legendy a Kroniky tř. Dalimila, takže se snaží prokázat starobylost mělnického opevnění, nebo připouštěji výrazné pochybnosti (srov. Profantová 1996; Meduna 2006, s. 18) - protože existenci mělnického hradiště $\mathrm{v}$ polovině 9 . století prozatím nelze ničím prokázat - a Pšov hledají v širším regionu Mělnicka, na lokalitách, u nichž je věrohodněji potvrzena existence opevnění ve starši fázi střední doby hradištní (800-950). S hledání Pšova v okolí Mělníka (Bosyně, Hradsko, Přívory, Vepřek) - jak se níže pokusíme doložit lze však jen stěží souhlasit. 
okolí je doloženo kontinuální osídlení od doby kamenné po současnost, a logicky tedy i ve starší a střední době hradištní. Jedná se o obecně známou dominantu středního Poohří, hradiště Rubín u Podbořan. Poloha je sice archeologicky také méně prozkoumána a její kulturní vrstvy byly v nedávné minulosti výrazně poškozeny, ale o tom, že na ní stálo ve starší i střední době hradištní opevněné sídlo s výraznou správní funkcí v regionu, se prakticky vůbec nepochybuje (srov. Bubeník 1995, 2006).

Rubín bývá někdy uváděn v souvislosti s Wogastisburgem (7. století) Fredegarovy kroniky nebo Canburgem (9. století) Moissacké kroniky, avšak bez průkazných argumentů. Podle našeho názoru by nás mělo více zajímat, že hradiště leží v takřka bezprostřední blízkosti obce Pšov, jejíž název ,př̌ežil” - i přes výrazné německé osídlení oblasti - do současnosti. Dále bychom měli vnímat jeho pozvolna se vytrácející důležitost na počátku 10. století a také to, že je částečně doloženo osídlení jeho předpolí s kontinuitou od raného středověku po současnost, a to ve směru od hradiště k dnešní obci - předpolí hradiště, poloha u starého hřbitova, současná obec (Bubeník 1992, s. 228). V neposlední řadě upozorňujeme na skutečnost, že bylo hradiště na vrchu Rubín během 10. století patrně zcela opuštěno a jeho centrální funkci nahradil nově budovaný přemyslovský Žatec. ${ }^{17}$

\section{Toponomastika}

Toponomastika řadí střední Čechy mezi nejstarší prostory země osídlené Slovany a region středního Poohří považuje za „západní část nejstaršího sídelního území” (Šmilauer 1960, s. 31). Roli výzkumu místních jmen bychom sice neměli přeceňovat, ovšem zcela se nevyhneme otázce, jak nahlížet na jména současných sídel ležících na ploše raně středověkých hradů nebo v jejich blízkosti a kde hledat motivace $\mathrm{k}$ jejich pojmenování.

${ }^{17}$ Paralely z jiných oblastí naší země (Kouřim, Plzeň) svědčí o oblibě přemyslovských knížat zakládat nové opěrné a správní body na dohled od starých center, jejichž upadající význam a zánik symbolizoval nové pořádky.
Upozorníme na několik vybraných toponym, uváděných nejen Kosmou, ale i dalšími domácími písemnými prameny raného středověku. Připomínáme tím známé skutečnosti, že obec Tetín leží na ploše hradu stejného jména; že se nedaleko obcí Libušín, Vlastislav a Lštění skutečně rozkládaly hradištní fortifikace shodných jmen, že lze vysoko nad dřevíčským dvorem najít kdysi dobře opevněné hradiště, že města Kouřim, Stará Boleslav, Bílina i Plzeň převzala jména po svých sídelních předchůdcích.

Pokud bereme na vědomí výše uvedené př́iklady, nabízí se možnost uvažovat obdobně o hrádku Pšovu. Z pozice dnes osídlených obcí připadají v úvahu jen dvě lokality, a to Pšov mezi Žluticemi a Manětínem, nedaleko něhož se vypíná proslulá hora Vladař s rozsáhlým pravěkým opevněním, a námi již uváděný Pšov u Podbořan. Pro Pšov u Žlutic prozatím nehovoří prakticky žádné hmotné doklady, oblast patrně nehrála ve střední době hradištní významnou roli, zato Pšov u Podbořan stojí v jiném světle.

Nesmíme ale také zapomenout na další výše zmíněnou okolnost, a tou je výskyt hydronyma Pšovka př́mo u středočeského Mělníka; jedná se o vodoteč protékající Kokořínským dolem směrem v Labi.

Pšovka je menší a poměrně nevýznamná říčka, takže úvahy, že se stala v raném středověku motivujícím prvkem pro pojmenování rozsáhlejší oblasti (provincia Psov), či dokonce lidu usedlého v přilehlém regionu (Psouane), nedávají hlubší smysl (Třeštík 1997, s. 68), přestože si uvědomujeme, že bývají právě hydronyma považována za velmi stará. Pokud připustíme motivační roli Pšovky, museli bychom nabídnout jiné paralely z dalších regionů Čech, ale hlavně vysvětlit, proč uvádí Kosmas jiné pojmenovávací mechanismy (viz poznámka č. 2), ${ }^{18}$ proč Kristiánův text - at' již přijmeme teorii o pozdní extrapolaci, či nikoli - nic takového nenaznačuje a proč dnes na mapě marně

${ }^{18}$ Důležitou okolnost k Mělníku uvádí A. Profous: „Podle onoho Pšova byla pojmenována také voda (potok) tekoucí pod Mělníkem Pšovka...” (Profous 1951, s. 499), ve srovnání s Berounkou a Chrudimkou i s uvedením nejstarší zmínky o hydronymu: „1268 super rivulum dictum Pshowka (RB. II, 238)”. A. Profous také převzal bez zjevných rozpaků informaci z Kristiánovy legendy o Pšovu - Mělníku. 
hledáme některé vodoteče ve středním Poohří uváděné Kosmou v souvislosti s popisem oblastí osídlených Lučany.

Ani tř. Dalimil nenaznačuje nic podobného; uvedením hydronyma (potůčku!) se jen snaží podpořit zmínku Kristiánovy legendy, že je Mělnicko totožné s P̌̌ovskem. Jeho informace však o stavu místa v 9 století nevypovídá, zato nás seznamuje s pravděpodobnou realitou počátku 14. století = opevněný Mělník a pod ním ,„potóček Pšovka...” nic víc.

Zbývá ale ještě vysvětlit okolnost, proč se oba Pšovy (dnešní obce) objevují jen v severozápadních Čechách a říčka Pšovka na Mělnicku. Oba regiony země sice můžeme právem považovat za oblasti s nejstarším slovanským osídlením Čech, ale jsou od sebe poměrně vzdálené a porovnáváme-li oblast kolem Pšova u Podbořan, o který především jde, a na Mělnicku směrem ke Kokořínskému dolu, jedná se o diametrálně odlišné scenérie. „Obilnici” 9. století uváděné P. Medunou rozhodně lépe odpovídá oblast stř̌edního Poohří než Mělnicka ve směru ke Mšenu, odkud přitéká Pšovka a kde je také historiky nezř́idka hledán Pšov (lokalita Hradsko u Kaniny).

Domníváme se, že byla oblast středního Poohří členěna v 9. století do blíže neurčitého počtu menších celků a nazývána $L u ́ k a=$ synonymum úrodné země, bohatých pastvin atp., jak uvádí Kosmas:

[...] quinta que in medio est, dicitur Luca, pulcherrima visu, et utillima usu ac uberrima satis nec non habundantissima pratis, unde et nomen ipsa regio traxit, quia luca latine pratum dicitur. Et quoniam hec regio primum, longe antequam Satc urbs condita foret, est inhabitata hominibus, recte eius incole sunt a regione Luczane nuncupati (Bretholz 1923, s. $23^{19}$ )

Patrně jedním z nejstarších a nejdůležitějších center v oblasti bylo hradiště Pšov (dnes vrch Rubín nad obcí Dolánky), jehož pojme-

19 „[...] pátá uprostřed, slove Lúka, překrásná na pohled a bohatá výnosem, velmi úrodná na osení a oplývající lukami, odkudž nabyla i svého jména. A poněvadž byla tato krajina nejdř́ve, dávno ještě před založením hradu Žatce, obydlen lidmi, právem se její obyvatelé nazývali po své krajině Lučané” (Kosmas 1975 , s. 26). nování patrně souviselo s pěstováním obilnin (srov. Profous 1951, s. 498-499; Šmilauer 1970, s. 150).

Přítomnost ojedinělého hydronyma Pšovka na Mělnicku se poté jeví v poměrně neotřelém, novém světle. Vysvětlení je jednoduché, otočíme-li dodnes přijímané starší teorie komunikující existenci tzv. přesídleneckých osad. ${ }^{20}$ Historikové i lingvisté totiž dosud mají s Pšovem na Podbořansku fatální problém, protože se jeho poloha vymyká obvyklým pohledům na vývoj mocenských struktur země v 9. a 10. století; nabízejí tedy teorii ztotožňující obec Pšov s přesídleneckou osadou - $\mathrm{k}$ transferu obyvatel mělo dojít maximálně do 10 . století, a to ze středočeského Mělnicka do středního Poohří.

Ovšem vzhledem $\mathrm{k}$ argumentům, které byly výše prezentovány, nabízíme hypotézu, že mohla být realita právě opačná a že došlo po některém $\mathrm{z}$ dramatičtějších konfliktů mezi vládci jednotlivých regionů Čech (patrně ještě v 9. století) ke koncentraci rozprchlého obyvatelstva v Poohří - v nížinné poloze Drahúš - (viz Kosmas 1975 s. 31$)^{21}$ a k jeho částečnému přesídlení do středních Čech, ${ }^{22}$ čímž byly rozvráceny dosavadní mocenské a sídelní struktury na straně po-

${ }^{20}$ V souvislosti s vesnicí Pšov u Podbořan bylo upozorňováno na „zavlečené pšovské zajatce” (Turek 1953, s. 13), což akceptoval i J. Bubeník realizující archeologický výzkum na vrchu Rubín, který uvádí existenci hradiště ve střední dobe hradištní, jako "ústředí raně středověkého sídelního celku ve stř̌edním Poohří” (Bubeník 2006, s. 34). V podobných intencích uvažoval i J. Sláma se zdůrazněním odvozování toponym od „správních (kastelánských) hradů” a s informací, že přesídlenecké osady „především chybí na původní přemyslovské středočeské doméně” (Sláma 1985, s. 337-338) Slámovo přesvědčení o chybějících přesídleneckých osadách $\mathrm{v}$ původní přemyslovské doméně si tedy nyní dovolujeme částečně korigovat.

${ }^{21}$ O Kosmových informacích se nezř́dka pochybuje, ale domníváme se, že v mnoha př́ipadech neoprávněně. Kronikář znal velice dobře středočeské centrum i regiony země (uvedl různé dominanty) a je nanejvýš zřejmé, že řadu uváděných lokalit $-\mathrm{v}$ jeho době neexistujících či zejících v rozvalinách - i osobně navštívil.

22 Přesídlené obyvatelstvo by podle naší teze přeneslo starou pšovskou tradic alespoň na pojmenování říčky vlévající se do Labe, ale již nebylo možné totéž realizovat u Mělníka, protože $\mathrm{v}$ té době ještě nestál, nebo byl teprve budován, a označení 
ražených. O možném zásahu zvenčí (Frankové, Moravané atp.) můžeme jen spekulovat, i když bychom se mohli částečně orientovat také na zahraniční písemné prameny zaznamenávající vojenské výpravy proti českým Slovanům.

\section{Epilog}

Po složitém uvažování a dokazování zbývá ještě jednou vysvětlit námi předložený pracovní pojem Kosmova kreativní nápověda. Nelze se k němu stavět kategoricky, ale nesporně stojí za pozornost. Kronikář pracoval na počátku 12 . století s různými písemnými i orálními prameny; a omezíme-li se nyní jen na pramennou podstatu jeho první knihy, je třeba především uvažovat o nejstarší české analistice, hagiografii a dále nelze opomíjet jím zmíněné bájné podáni starcư tradované z generace na generaci či interpretované přednašeči uměleckých epických látek.

Přirozeně nevíme, ze kterých dalších pramenů mohl vycházet, předpokládáme ale, že kromě literárních podkladů dobře znal české mocenské prostředí i stav země - na jeho dobu se nadstandardně orientoval nejen v dávném odkazu předků, nýbrž i v krajině. Můžeme sice připustit značnou míru Kosmovy fantazie i fabulačního talentu, ale budeme-li i nadále tvrdit (nemáme-li jiný argument), že si značnou část příběhů prostě jen vymyslel, musíme současně vysvětlit, kde např́iklad vzal legendista Kristián bezejmennou hadačku obdařenou nadprůměrnými schopnostmi, jež pojala za chotě Přemysla a předpověděla založení Prahy, o níž píše Kosmas jakožto o Libuši, a proč nacházíme řadu sídelních lokalit přesně tam, kam je kronikář situoval, atp.

Předpoklady, jakými postupy Kosmas finalizoval primární autograf kroniky, se sice dnes více méně pohybují (a vždycky budou) na bázi nedoložitelných spekulací, ale i tak přicházíme s teorií o Kos-

správního hradu starým toponymem nebylo žádoucí - podobně jako u Žatce. Přesídlené obyvatelstvo mohlo být využito právě ke stavbě nové fortifikace, nebylo-li prodáno do otroctví (srov. Novotný 2009, s. 9-26). mově kreativní nápovědě, která může souviset s motivem původu kněžny Ludmily. Úvahy o Ludmilině původu situovaném na hradiště Rubín u Podbořan lze podpořit alespoň nepř́mými důkazy - literárními, lingvistickými i archeologickými, avšak názory na Kosmův reálný př́istup ke komponování archetypu první knihy Kroniky Čechi̊ je třeba považovat za navýsost hypotetické.

Do debaty o tom, proč byl př́běh o tragickém konci bojovného Vlastislava vložen mezi data knížete Bořivoje I. a jeho manželky Ludmily, přestože autor kroniky jasně uvádí, že se vyprávěné události odehrály „dávno předtím”, je potřeba zahrnout několik možností. Kosmas mohl epizodu do celku vložit bezděčně, při kontinuální práci na výsledném textu, na jehož podkladech jistě pracoval řadu let. Mohl se ovšem také dopustit chronologické chyby, když zapomněl uvést Vlastislavův příběh dříve a svoje pochybení částečně napravil na místě, kde se již rozepisoval o Bořivojově osobě.

Připustíme-li však Kosmovu kreativni nápovědu, byla epizoda líčící průběh lucké války vložena $\mathrm{k}$ Bořivojovým a Ludmiliným osudům $\mathrm{z}$ toho důvodu, aby autor naznačil vazbu mezi oblastí země ovládanou Lučany a Ludmiliným původem z hrádku Pšova (castellum Psov), jehož skutečnou lokaci nestandardně směřujeme tímto příspěvkem právě do oblasti středního Poohřrí. Připustíme-li takovou možnost, je třeba přemýšlet o příčinách kronikářových rozhodnutí. Proč Kosmas postupoval s tak vysokou mírou rafinovanosti či obezřetnosti? Nebyl si jist lokací starobylého Pšova? Nebo naopak znal na počátku 12. věku - na rozdíl od Kristiána - pravou polohu zaniklého hradiště a nemohl o ní (z nám neznámých důvodů) psát př́mo?

\section{Literatura}

B lá h o vá Emilie, K o n z a l Václav (eds.), 1976, Staroslověnské legendy českého původu. Nejstarši kapitoly $z$ dějin česko-ruských kulturnich vztahù. Praha: Vyšehrad.

B lá h o vá Marie, 1996, Evropská sídliště v latinských pramenech období raného feudalismu. Praha: Univerzita Karlova. 
Br e th o 1 z Bertold (ed.), 1923, Die Chronik der Böhmen des Cosmas von Prag. In Monumenta Germaniae Historica, Nova series II. Berlin: Weidmannsche Buchhandlung, s. 1-241.

B ubeník Josef, 1992, Výzkum vrchu Rubín (Dolánky, obec Podbořany, okr. Louny) a jeho okoli v letech 1984-1989. „Archeologické rozhledy” 44, č. 2, s. $216-230$.

B ube ník Josef, 1995, K opevnění vrchu Rubinu u Podbořan. „Archeologické rozhledy" 47 , č. 1, s. 128-151

B u b e ník Josef, 2006, Hradiště Rubín u Podbořan v SZ Čechách v raném středověku. „Studia mediaevalia Pragensia”, č. 7, s. 21-37.

D a ňhe 1 k a Jiří aj. (eds.), 1988, Staročeská kronika tak řečeného Dalimila (1). Praha: Academia.

E m l e r Josef (ed.), 1874, Cosmae Chronicon Boemorum cum continuatoribus. In Fontes rerum Bohemicarum. Tom. II. Praha: Museum Království českého, s. $1-198$.

C h a 1 o u p e c k ý Václav (ed.), 1939, Prameny X. století legendy Kristiánovy o svatém Václavu a svaté Ludmile. In Svatováclavský sbornik: na památku 1000. výroči smrti knižete Václava Svatého. Díl II. V Praze: Národní výbor pro oslavu svatováclavského tisíciletí.

C h a lo u p e c ký Václav aj., 1942, Na úsvitu křestanství. Z naši literární tvorby doby románské v století IX.-XIII. Praha: Evropský literární klub.

K a r b u s i c k ý Vladimír, 1995, Báje, mýty, dějiny: Nejstarší české pověsti v kontextu evropské kultury. Praha: Mladá fronta.

K o s m a s, 1975, Kosmova kronika česká, eds. Zdeněk Fiala, Marie Bláhová, 6. vydání. Praha: Svoboda.

L u d ví k o v s k ý Jaroslav (ed.), 1978, Kristiánova legenda. Život a umučeni svatého Václava a jeho báby svaté Ludmily. Praha: Vyšehrad.

M e d u n a Petr, 2003, Nejstarši raně středověké opevněni v areálu Mělnika. „Archeologické rozhledy" 55 , č. 2, s. 378-385.

M e d u n a Petr, 2006, Ludmila z kraje slovanského. In: Nomine Liudmilam: sborník praci k poctě svaté Ludmily. Mělník: Město Mělník, s. 14-22.

N o v o tn ý Jiří, 2009, Motivy zotročováni v nejstarši české literatuře. In Moje oči musely vidèt... Téma a motivy násili v české a slovenské literatuře. Opava: Slezská univerzita v Opavě, s. 9-26.

No v o tn ý Jiří, 2013, Comex, dux, princeps. In Sborník přispěvků z mezinárodní védecké konference. Mezinárodni Masarykova konference pro doktorandy a mladé vědecké pracovniky IV/2013. Hradec Králové: Magnanimitas, s. $2984-2989$.

P r o fa n t o vá Nad'a, 1996, Kněžna Ludmila. Vládkyně a světice, zakladatelka dynastie. Praha: Epocha.
P r o fa n t o vá Nad’a, 2006, Život kněžny Ludmily drama na prelomu epoch. In Nomine Liudmilam: sbornik prací k poctě svaté Ludmily. Mělník: Město Mělník, s. 23-33.

Pro fou s Antonín, 1951, Mistní jména v Čechách: jejich vznik, původní význam a změny. Díl III. $M-\check{R}$. Praha: Česká akademie věd a umění,.

S lá m a Jiří, 1985, Kněkterým ekonomickým a politickým projevưm raně středověkého přemyslovského státu. „Archeologické rozhledy” 37, č. 3, s. 334-342.

S̆ m i 1 a u e r Vladimír, 1960, Osídleni Čech ve světle mistních jmen. Praha: Nakladatelství Československé akademie věd.

Š m i 1 a u e r Vladimír, 1970, Př́ručka slovanské toponomastiky. Praha: Academia.

T o m á š e k Jan, 2020, Ludmila ze země Srbů. In: Ludmila: kněžna a světice. Praha: Nakladatelství Lidové noviny, s. 75-87.

T o m á š e k Jan, I z d n ý Jakub, 2020, De provincia Melnicensi. In Ludmila: kněžna a světice. Praha: Nakladatelství Lidové noviny, s. 59-74.

Tř eštík Dušan, 1966, Kosmas. Studie s výběrem z Kosmovy Kroniky. Praha: Svobodné slovo.

Tř e štík Dušan, 1997, Počátky Přemyslovců. Vstup Čechů do dějin (530-935). Praha: Nakladatelství Lidové noviny.

T u r e k Rudolf, 1953, Kmenová území v Čechách. „Časopis Národního musea” 121 s. $3-46$.

T u re k Rudolf, 1975, Česká hradiska u Kristiána. In: Classica atque medievalia Jaroslao Ludvíkovský octogenario oblata. Brno: Universita J. E. Purkyně, s. $139-149$ 